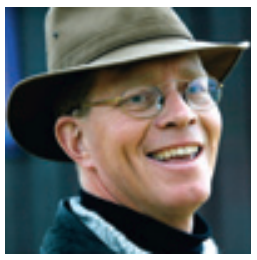

\title{
Å være nyretransplantert
}

\section{Erfaringer fra en nyretransplantasjon}

Jeg vil på det sterkeste anbefale folk å bli nyretransplantert. Fordelene er mange og store. Den mest åpenbare er at man våkner av narkosen med en formidabel følelse av å være gjenfødt. Her har man hanglet seg gjennom tusentallige dager som en slagghaug i menneskehud. Det plutselig rensede blodet gjør at hodet og tankene oppleves klarere enn på mange år. Først etter operasjonen skjønner man hvor ille det var fatt med ens legeme før innleggelsen. Det oppleves som å våkne av en lang, hutrende og tungsindig dvale. Eller for å si det med Kolbein Falkeid: Det føles som å komme hjem til den grønnmalte gleden i sydveggen av sinnet ditt.

I noen tilfeller blir viriliteten i veldigste laget. For en tid siden kunne man lese $i$ avisen om en amerikansk kvinne som hadde fått en av sin manns nyrer. Hun forelsket seg straks etter operasjonen i fysioterapeuten og stakk av med ham. Den forsmådde donor ga henne valget mellom å gi tilbake nyren eller betale 10 millioner dollar i erstatning. Hvordan det endte, vet jeg ikke. Derimot kan det bekreftes at min kontakt med fysioterapeuten var reservert under den gruppevise nyretrimmen hver morgen mellom ni og ti.

À være nyretransplantert betyr at man får noe vesentlig til felles med mennesker man aldri før har hatt noe felles med. Halv åtte om morgenen samles de transplanterte til blodprøvetakning. Tenåringer, gamlinger, noen med hijab, andre i treningsklær, enkelte med krykke. Hvordan går det, spør man hverandre, på 30 ulike dialekter og tungemål. Uten omsvøp serveres svarene. Hvis alle mennesker var så åpne, direkte og fasadeløse som nyretransplanterte, tenker man ved seg selv at jorden ville vært et paradis.

$\AA$ være nyretransplantert gjør det lettere å gripe øyeblikket. Man våkner ikke til en ny dag med samme grad av selvfølgelighet. Hvilket utløser tanker om hva man ønsker å bruke sine gjenvunnne krefter til. Som nyretransplantert oppdager man hvilke mennesker man betyr noe for, ganske enkelt ved at de utviser interesse og omsorg. Man blir overrasket over den taushet som utvises fra enkelte. Det er en avklarende erfaring. Fra sykesengen ser man at de menneskene som betyr noe i ens liv er de menneskene som man selv betyr noe for.

Å være nyretransplantert betyr at man fylles av takknemlighet. Først og fremst overfor ens donor, som i mitt tilfelle er den kvinnen jeg har vært gift med i 22 år. Å bære en av hennes nyrer gjør at jeg med større rett enn Frank Sinatra kan avsynge «I've got you under my skin». Problemet med å motta en gave som dette er hva i all verden man kan gi tilbake. Dessverre er det ingen av mine kroppsdeler hun har lyst på. Hun har 80000 gram å velge mellom, men rister bare på hodet. Så får jeg isteden bestrebe meg på å bli et bedre menneske. Trøsten må være at det, ifølge mange mennesker, ikke skal så mye til i mitt tilfelle.

Jeg har vært spent på om det vil nappe i nyren når jeg er nær min tapre kone. Nyrer mestrer nå en gang så mange kompliserte arbeidsoppgaver at det ville være rart om de ikke kunne føle hjemlengsel. Svaret er ja. Det napper, og som hobbyfisker må det innrømmes at dette er de eneste nappene jeg har opplevd siden transplantasjonen.

I tillegg til den iblant nappende angsten forbundet med tanken på at det implanterte organet kan avstøtes.

Takknemlig blir man også overfor kirurgene og pleierne ved Rikshospitalet. Dette at pasienter kommer kavende inn som menneskevrak og i løpet av få dager forvandles til glødende friske vesener med energi og livsmot, tilfører avdelingen for transplantasjonskirurgi et preg av et evangelisk helbredelsesstevne hvor «herlige ting vil skje», som det heter i reklamen. Her skjer det samme - uten noen påviselig bistand fra oven. Derfor stortrives de ansatte ved avdelingen. Medvirkende er det i så måte antakelig også at avdelingen har ord på seg for å være i fremste verdensklasse. Prestisjen tilfører utvilsomt avdelingen stolthet, ressurser og høye ambisjoner. Alt sammen $i$ åpenlys favør av den enkelte pasient.

Spørsmålet er naturligvis hvor mange legemsdeler man kan bytte ut før man opphører å være seg selv. Selv opplever jeg å ha blitt vesentlig mer feminin når jeg nå er blitt bærer av min kones nyre. Plutselig lurer jeg på hvordan min mor har det, og har endog knepet meg selv i å plukke markblomster. Kvinner er ikke nødvendigvis bedre mennesker, men det foreligger mange indikasjoner på at de er oftere mennesker. I så måte har jeg et håp om at nyren vil feminisere meg ytterligere.

$\AA ̊$ være nyretransplantert betyr at man utvikler større forståelse, sympati og medlidenhet med dem som er kronisk syke. Man erfarer hvor degraderende det er å forvandles fra avholdt bidragsyter til belastning og utgiftspost. Når man ligger med buken i været, pleietrengende, medikamentavhengig og hjelpeløs, med kateter og smertepumpe, finnes det bare en dugelig realøkonomisk trøst. Det består i at dette trolig blir det nærmeste man noen gang kommer sin rettmessige andel av nasjonens ebbende oljeeventyr. For snipp, snapp snute, så er både eventyret og pasienten ute.

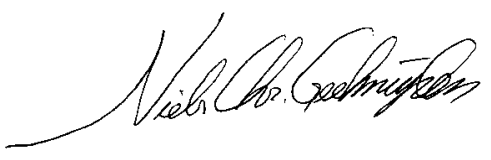

\section{I neste nummer:}

Depresjon og hjertesykdom

Anestesi ved keisersnitt

Brystkreft
Smerter hos LAR-pasienter

Stikkskader

Obduksjoner 